\title{
Örgütlerde Grup Düşünüşün Sessizliğe Etkisi Üzerine Ampirik Bir Araştırma
}

\author{
An Empirical Study on The Effect of The Groupthink on Silence in Organizations
}

\section{Ufuk ORHAN ${ }^{1}$}

\begin{abstract}
ÖZET
Araştırma, bir otomotiv firmasında grup düşünüşün, sessizliğe etkisini ortaya koyma amacıyla yapılmıştır. Araştırmanın sorunsalının grup düşünüş ile sessizlik etkileşimi üzerine kurgulanması, iş görenlerin iş arkadaşlarından destek bulmadıkça ses çıkartmayacakları ve yanlış bile olsa genellikle çoğunluk ile aynı fikirde olmaya gayret etmeye meyilli olmalarından kaynaklanmaktadır. Grup Düşünüş semptomları; "tehlikeye açık olunmadığı illüzyonu, grubun ahlaki değerlere sahip oldukları inancı, kolektif rasyonalizasyon, grupların basmakalıpları, kendini denetleme, görüş birliği illüzyonu, muhaliflerin üzerine doğrudan baskı ve kendini akıl koruyucuları tayin edenler"i içermektedir, sessizlik ise tek boyutta incelenmiştir. Araştırmanın örneklemini, özel sektör çalışanlarından oluşan 96 kişi oluşturmaktadır. Araştırmada verilerinin değerlendirilmesi adına tanımlayıcı istatistiksel metodlar, normal dağılım için Kolmogorov Smirnov testi, değişkenler arası ilişki için Pearson Korelasyon ve Grup Düşünüşün Sessizliğe etkisini ölçmek için ise Regresyon analizi yapılmıştır. Araştırmanın bulgularına göre; kendini denetleme, sessizliği artırmaktadır ve grup düşünüş ve semptomları, bazı demografik özelliklere göre farklılık arz etmektedir.
\end{abstract}

Anahtar Kelimeler: Sessizlik, Grup Düşünüş, Otomotiv Sektörü.

\section{GíRiş}

İlgili yazınlarda hem sosyal yaşamın bir parçası olan bireylerin hem de iş yaşamının önemli aktörleri olan yöneticilerin iş, sosyal ilişkiler ve benzeri kavramları kaybetme korkusu ile iletişim bariyerleri kurmaları ve tek başlarına karar ver(e)memeleri üzerine birçok yazı yer almaktadır. Illetişim bariyeri olarak, çalışanın işyerinde konuşmaması, çekinik veya sessiz kalması çalışanı sessizliğe; tek başına karar vermekten çekinme anlamında olumsuz sonuçların risklerini paylaşmak, ait olduğu gruptan aforoz edilmemek gibi insani nedenler ise çalışanı grup

\begin{abstract}
The present study has been conducted in order to reveal the influence of groupthink on silence in a automotive company. That the problematique of the study has been constructed on the interaction between groupthink and silence derives from the fact that workers will not tend to raise objections unless they find support from colleagues (and that they often endeavor to affirm the majority opinion, even if it is wrong). The symptom of Groupthink includes illusion of invulnerability, belief in inherent morality of the group, collective rationalization, stereotypes of out-groups, selfcensorship, illusion of unanimity, direct pressure on dissenters and self-appointed mindguards and silence has been investigated in one dimension. The sample of the study consists of 96 employees who work in private sector. In analyzing process of the data, techniques of descriptive statistics, test of Kolmogorov Simirnov for normal distribution, Pearson corelation for the correlation between parameters and regretion analysis was used for the effect of groupthink over silence. The findings of the study proved that the self-censorship increases the silence and groupthink and its sympthoms may differ according to some demographical qualities.
\end{abstract}

Keywords: Silence, Groupthink, Automotive Sector.

düşünüşe sevk edebilmektedir.

Çalışma iki kavram arasındaki ilişkiyi açıklamayı amaçlamakta ve çalışmanın bireyin grup etkisi ile kararlara katılımının ve sessizlik sergilemesinin örgütlerde istenmeyen birçok davranışın öncülü veya artçısı olması ihtimali açısından önemli olduğu düşünülmektedir.

Çalışma giriş ile birlikte dört bölümden oluşmaktadır. Aşağıda literatür özeti yer almaktadır. Üçüncü bölümde yöntem, son bölümde ise sonuç ve tartışma bölümü yer almaktadır. 


\section{LITERATÜR ÖZETi}

Grup, Johnson ve Johnson'a göre, iki ya da daha fazla sayıda bireyin yüz yüze etkileşime girdiği, her birinin kendi grup üyeliğinin farkında olduğu, her birinin gruba üye olan diğer kişilerin farkında olduğu ve her birinin ortak hedeflere ulaşmaya çalışırken kendi pozitif bağımlılıklarının farkında olduğu bir oluşumdur (Hogg ve Vaughan, 2007:305). Grup etkileşiminde bir dizi grup normuyla beraber statü ve roller ve bunların sahipleri istikrara kavuşur (Gönüllü, 2001: 192). Gerek grubun bireye etkisi (grup dinamiği), gerek ise grup davranışı ile bireyler arası etkileşimin örgüt davranışını etkileyen güçlü bir kuvvet (Büyükgebiz vd., 2000: 207) olması, grupların örgütsel birçok konu ile yakından ilişkili olduğu intimali doğurmaktadır. Grup dinamiği, insanları psikolojik ve örgütsel anlamda etkileyen bir kavram olması açısından önemlidir ve Newstrom ve Davis'e (1997: 340) göre insanların küçük gruplar içinde yüz yüze etkileşimiyle oluşan sosyal bir süreçtir. Grup dinamiği kavramı, bireyin gerek aidiyet, gerek ise dışlanma ve benzeri korku duyguları gibi öncelikleri uğruna birey olarak karar verememesi sonucunda grup düşünüş kavramına sebebiyet verebilmektedir. Grup düşünüş Janis tarafından, "kişilerin etkili bir grup içinde yer aldıklarında kendilerinin de bir şekilde dâhil olduğu bir düşünme şekli; grup üyelerinin yapılması planlanan iş için gerçekçi alternatif yolları önerirken motivasyonlarının çok yüksek düzeyde olduğu durum" olarak tanımlanmıştır (Celmer, 2007:12-13). Janis ve Mann tarafından ise, "grupça karar verenleri daha ileri iş bitirme noktasına doğru yönlendiren bir fenomen ve rahatsızlık veren gerçeklerden kaçınmayı sağlayan toplu bir savunma örüntüsü" (Celmer, 2007:12-13) ve "ortadaki bir grup kararının daha kabul edilmeden desteklenmesi" olarak açılanmıştır (Kyle, 1980:15). Janis, sekiz adet grup düşünüş semptomu ortaya koymuştur (Janis, 1982:174-175):

Tablo 1: Grup Düşünüş Semptomları

\begin{tabular}{|l|l|}
\hline $\begin{array}{l}\text { Tehlikeye Açık } \\
\text { Olunmadığı Illüzyonu }\end{array}$ & $\begin{array}{l}\text { Grup üyelerinin çoğu veya tümünün, aşıı iyimserliği yaratırken ve büyük riskleri alırken cesaretlendirilmesine } \\
\text { neden olan ortak illüzyondur. }\end{array}$ \\
\hline $\begin{array}{l}\text { Grubun Ahlaki } \\
\text { Değerlere Sahip } \\
\text { Oldukları İnancı }\end{array}$ & $\begin{array}{l}\text { Grup üyelerinin verdikleri kararların etik ve ahlak bakımından sonuçları konusunda kendilerini görmezden } \\
\text { gelmeye indirgeyen ortak inançtır. }\end{array}$ \\
\hline $\begin{array}{l}\text { Kolektif } \\
\text { Rasyonalizasyon }\end{array}$ & $\begin{array}{l}\text { Grup üyelerinin kendilerini geçmişteki politika kararlarına endekslemeden önce, varsayımlarını yeniden } \\
\text { gözden geçirmelerine yol açabilecek uyarı veya bilgilere karşı gösterdikleri isteksizlik çabalarıdır. }\end{array}$ \\
\hline $\begin{array}{l}\text { Grupların Basma } \\
\text { Kalıpları }\end{array}$ & $\begin{array}{l}\text { Grup üyelerinin, muhalif grupların bir araya gelinemeyecek kadar kötü olduklarını göstermek için çok fazla } \\
\text { gayret içinde olma eğilimidir. }\end{array}$ \\
\hline Kendini Denetleme & $\begin{array}{l}\text { Grubun üyelerinden herhangi birinin görüşü, grubun görüşünden uzaklaştığında grup üyesinin kendi } \\
\text { görüşlerini gönüllü olarak denetlemesidir. }\end{array}$ \\
\hline $\begin{array}{l}\text { Görüş Birliği illüzyonu } \\
\text { Grup üyelerinin, çoğunluk görüşünü doğrulama çabalarına ilişkin ortak illüzyonudur. }\end{array}$ \\
\hline $\begin{array}{l}\text { Muhaliflerin Üzerine } \\
\text { Doğrudan Baskı }\end{array}$ & $\begin{array}{l}\text { Grup üyelerinin aykırı görüşlerde ısrar edenlere gösterdiği tepkinin, tüm sadık üyelerden beklenen bir } \\
\text { davranış olduğunun netleştirilerek grup üyeleri tarafından gruba muhalif görüşlerde olanlara baskının } \\
\text { uygulanmasıdır. }\end{array}$ \\
\hline $\begin{array}{l}\text { Kendini Akıl } \\
\text { Koruyucuları Tayin } \\
\text { Edenler }\end{array}$ & $\begin{array}{l}\text { Grubun, kendi kararlarının etkililiği ve ahlakiliği ile ilgili kayıtsızlığını yok edebilecek çeşitli enformasyonlardan } \\
\text { kendini koruma durumudur. }\end{array}$ \\
\hline
\end{tabular}

Sessizlik, Henriksen ve Dayton'a göre bir örgütün karşılaştığı önemli sorunlara çözüm üretebilecek düşüncelerle ilgili çok az konuşmak ya da davranışta bulunmak şeklinde ifade edilen kollektif düzeyde bir olgu; Bowen ve Blackmon'a göre ise örgütsel hareketleri etkileyebilmek için çalışanın görüşlerini gönüllü olarak açıklaması olarak tanımladıkları sesin zıttı (Akt: Özdemir \& Sarıoğlu Uğur, 2013:261) olarak tanımlanmıştır. Yine Dyne vd.'e göre sessizlik, konuşmanın olmaması veya açık bir şekilde anlaşılabilecek bir davranışın olmayışı olarak tanımlanmıştır (Akt: Eroğlu vd., 2011:99). Yazında sessizlik kavramı ile ilgili farklı çalışmalar mevcuttur. Fakat kavramsal olarak bu çalışmalara konu olan sessizliğin örgütsel sessizlik mi yoksa çalışan sessizliği mi olduğu çoğu kez tartışmaya konu olmuştur. Brinsfield'in de belirttiği üzere (2009:19) örgütsel sessizlik ve çalışan sessizliği çoğu kez birbirine karıştırılmaktadır. Araştırmamızda, çalışan sessizliği ele alınmıştır. Sessizlik yönetim yazınının da kabul ettiği üzere anlaşılması zor bir konudur çünkü tanımında çelişkili özellikleri barındırır. Örneğin 
Pinder ve Harlos'a göre sessizlik; insanları hem bir araya getirebilir hem de birbirinden uzaklaştırabilir, insan ilişkileri açısından bazen zararlı olabilir bazen de düzeltici de olabilir, hem bilgi sağlamakta hem de gizlemektedir, bazen derin düşünmenin bazen de düşünce yokluğunun işareti olmaktadır ve hem onay hem de muhalefetin bir göstergesi olabilir (Eroğlu vd., 2011:99-100; Çakıcı, 2007:148-149). Sessizliğin anlaşılması zor bir konu olmasında etkili olan bir diğer faktör de farklı kültürlerde farklı amaçlar için kullanılmasıdır. Örneğin sessiz kalmayı Japon öğrencilerin genellikle saygınlık ve itibarı korumak için kullandığı, Avusturyalı öğrencilerin ise sessiz kalmak yerine sözlü stratejileri daha sık kullandıkları görülmüştür (Çakıcı, 2007:148). Araştırmacılara göre sessiz kalmada; şikâyetçi biri olarak görülmek, saygı ve güven kaybına uğramak, ilişkilere zarar vermek, işten atılmak, terfi edememek gibi korkular ile açıkça konuşmanın fayda etmeyeceği inancı temel rol oynamaktadır. Bowen ve Blackmon'a göre kişinin, grup üyeleri tarafından destek görüp görmeyeceğine ilişkin algısı da sessizlik tercihinde etkili olmaktadır (Çakıcı, 2008:119). Ayrıca sessizliğin nedenleri arasında; örgütsel nedenler, adaletsizlik kültürü, sessizlik iklimi, örgüt kültürü, yönetsel nedenler, yöneticilerin olumsuz geribildirim korkuları, iş ve işgörene olan önyargılı inanışlar, yöneticinin yapısı, yönetim ekibinin homojenliği, bireysel nedenler, güven eksikliği, konuşmanın riskli bulunması, izolasyon korkusu, geçmiş tecrübeler, ilişkileri zedeleme korkusu, karakter özellikleri, kültürel yapı ve normlar, güç mesafesi, ulusal ve kültürel nedenler de yer almaktadır (Eroğlu vd., 2011:102103). Sessizliğin çalışanlara ve örgütlere olumsuz etkileri bulunmaktadır. Sessizliğin örgütsel etkileri arasında; çalışanların fikri katılımlarının olmaması, sorunların hasıraltı edilmesi, olumsuz geribildirimden kaçınılması, bilgilerin filtrelenmesi ve sorunlar karşısında tepkisizkalınması yer almaktadır. Sessizliğin çalışanlar üzerindeki olumsuz etkileri arasında ise bireyin işyeriyle ilgili sorun ve endişelerini açıkça konuşmakta güçsüz olduğunu hissetmesi; örgüte bağlılık, aidiyet, güven, takdir ve destek duygusunda azalma, iş doyumu sağlayamama ve işten ayrılma isteği yer almaktadır (Çakıcı, 2008:119).

Bowen ve Blackmon bu teoriyi örgütsel bağlamda kullanarak, örgüt çalışanlarının iş arkadaşlarından destek bulmadıkça ses çıkartmayacaklarını vurgulamaktadırlar. Insanlar, hatalı bile olsalar genellikle çoğunluk ile aynı fikirde olmaya gayret ederler (Çakıcı, 2007:153). Yine grup düşünüş fikirlerin paylaşılmadan veya sorgulanmadan kayıtsız şartsız kabul edilmesidir ve sessizlik ile birlikte mevcut olması örgütlere zarar verebilir. Nitekim bazı çalışmalarda çalışanların fikir ve kaygılarını paylaştığında, grup ve örgüt işleyişinin daha iyi; sessizlik düzeyinin yüksek olması durumunda ise performansın kötü olduğu yer almaktadır (Morrison, 2014: 187). Ayrıca grup düşünüş aşırı da olsa sessizlik kültürünün bir biçimidir ve sessizlik kültürü, olumlu değişimi ve grup büyümesini sağlayan (yaratıcı) bireysel kuşkuya zarar verir (O'Grady and Meinecke, 2015:7). Aşağıda çalışmanın yöntemi hakkında bilgiler yer almaktadır.

\section{YÖNTEM}

\subsection{Araştırmanın Amacı, Önemi ve Sınırlılıkları}

Bu çalışma, Türk yönetim yazınında sessizliğin grup düşünüş üzerine etkisine ilişkin çalışmaların sınırlı olması açısından önem taşımaktadır ve tarama araştırmasıdır. Araştırmanın amacı çalışanların yaşadıkları sessizliğin sahip oldukları grup düşünüşten ne şekilde etkilendiğini ortaya koymaktır. Araştırma, zaman ve maliyet kısıtları göz önüne alınarak Adana'da otomotiv sektöründe faaliyet gösteren bir firmanın çalışanları ile sınırlandırılmıştır. Araştırmada yazına katkı sağlamak amacı ile aşağıdaki araştırma sorularına (A.S.) yanıtlar aranmıştır:

A.S. 1: Tehlikeye açık olunmadığı illüzyonu, çalışanların yaşadığı sessizliği etkilemekte midir?

A.S. 2: Grubun ahlaki değerlere sahip oldukları inancı, çalışanların yaşadığı sessizliği etkilemekte midir?

A.S. 3: Kolektif rasyonalizasyon, çalışanların yaşadığı sessizliği etkilemekte midir?

A.S. 4: Grupların basmakalıpları, çalışanların yaşadığı sessizliği etkilemekte midir?

A.S. 5: Kendini denetleme, çalışanların yaşadığı sessizliği etkilemekte midir?

A.S. 6: Görüş birliği illüzyonu, çalışanların yaşadığı sessizliği etkilemekte midir?

A.S. 7: Muhaliflerin üzerine doğrudan baskı, çalışanların yaşadığı sessizliği etkilemekte midir?

A.S. 8: Kendini akıl koruyucuları tayin edenler, çalışanların yaşadığı sessizliği etkilemekte midir? 
A.S. 9: Grup düşünüş genel puanı, çalışanların yaşadığı sessizliği etkilemekte midir?

A.S.10: Sessizlik ve Grup düşünüşün (ve semptomlarının) demografik özelliklere göre ortalamalarında farklılıklar mevcut mudur?

\subsection{Araştırmanın Örneklemi}

Anket soruları Adana'da otomotiv sektöründe faaliyet gösteren bir aile işletmesinin kolayda örneklem olarak belirlenen 96 çalışanına uygulanmıştır. Örneklemin bulunduğu işletme, 1968 yılında kurulan, İstanbul Sanayi Odası tarafından açıklanan "Türkiye'nin 500 Büyük Sanayi Kuruluşu 2014 Araştırması" listesinde yer alan ve 1800 ile 2000 arasında çalışanı bulunan bir kurumdur.

\subsection{Veri Toplama Araçları}

Araştırmanın veri toplama aracı ankettir. Araştırmada kullanılan anket formu üç kısımdan oluşmaktadır. Anketin ilk kısmında 6 maddeden oluşan demografik sorular yer almaktadır. Anketin ikinci kısmını 27 maddelik grup düşünüş soruları oluşturmaktadır. Son bölümde ise 12 maddeden oluşan sessizlik soruları yer almaktadır. Dolayısı ile anket formunda toplam 45 soru yer almaktadır. Anket maddelerinin puanlaması, Likert tipi $5^{\prime}$ li derecelendirme ile yapılmıştır. Bunun için kişilerin verilen önermelerle ilgili görüşlerini, çok olumludan çok olumsuza kadar sıralanan seçeneklerden belirtmeleri istenmiştir. Buna göre;(5) kesinlikle katılıyorum,(4) katılıyorum,(3) kararsızım,(2) katılmıyorum,(1) kesinlikle katılmıyorum şeklinde bir ölçek kullanılmıştır. Araştırmada kullanılan ölçekler; Comrey ve Newmeyer'in 1965 yılında oluşturdukları grup düşünüş ölçeği (Park, 1989:158-159) ve Erenler'in geliştirdiği sessizlik ölçeğidir (Erenler, 2010:201-202).

\subsection{Araştırmanın Güvenilirliği}

Ölçeğin güvenilirliğinin test edilmesinde Alfa Katsayısından (Cronbach Alpha) yararlanılmıştır. Yapılan analizlerde Sessizlik ile Grup Düşünüş (ve semptomlarının) genel güvenilirlik katsayıları Tablo 2'de verilmiştir.

Tablo 2: Sessizlik ile Grup Düşünüş (ve Semptomlarının) Güvenilirlik Katsayıları

\begin{tabular}{|l|l|}
\hline Sessizlik (Cronbach Alpha) & \multicolumn{1}{|c|}{ Grup Düşünüş Semptomları (Cronbach Alpha) } \\
\hline & Grup Düşünüş $(0,845)$ \\
\cline { 2 - 3 }$-0,834$ & Tehlikeye Açık Olunmadığı Illüzyonu $(0,716)$ \\
\cline { 2 - 3 } & Grubun Ahlaki Değerlere Sahip Oldukları İnancı $(0,826)$ \\
\cline { 2 - 3 } & Kolektif Rasyonalizasyon $(0,739)$ \\
\cline { 2 - 3 } & Grupların Basma Kalıpları $(0,763)$ \\
\hline & Kendini Denetleme $(0,786)$ \\
\cline { 2 - 3 } & Görüş Birliği Illüzyonu $(0,769)$ \\
\cline { 2 - 3 } & Muhaliflerin üzerine Doğrudan Baskı $(0,838)$ \\
\hline & Kendini Akıl Koruyucuları Tayin Edenler $(0,813)$ \\
\hline
\end{tabular}

Tüm faktörlerin güvenilirlik değeri 0.70'in üzerinde olduğundan anket güvenilirliğinin yüksek oluğu kabul edilmiştir.

\subsection{Verilerin Analizi}

Veriler değerlendirilirken tanımlayıcı istatistiksel metotlar (Sayı, Yüzde, Ortalama, Standart sapma) kullanılmıştır. Demografik özelliklerin ölçekler ile karşılaştırılmasında Anova ve t-testi kullanılmıştır.

Verilerin değerlendirilmesinde gruptaki denek sayısı yeterli değilse ya da denek sayısı yeterli olduğu halde veri parametrik test varsayımlarını yerine getiremiyorsa parametrik olmayan yöntemler kullanılır (Kalaycı, 2008). Araştırmanın değişkenleri için parametrik test varsayımlarından normal dağılım analizi uygulanmıştır. Değişkenlerin normal dağılımını gösteren Kolmogorov Smirnov testi sonucunda değişkenlerin normal dağılım gösterdiği görülmektedir. Verilerin analizinde parametrik yöntemler tercih edilmiştir. 
Tablo 3: One-Sample Kolmogorov-Smirnov Normal Dağılım Testi

\begin{tabular}{|c|c|c|c|}
\hline Grup Düşünüş Semptomları ve Sessizlik & $\mathbf{N}$ & $\mathbf{Z}$ & $\mathbf{p}$ \\
\hline Tehlikeye Açık Olunmadığı Illlüzyonu & 96 & 1,829 & 0,002 \\
\hline Grubun Ahlaki Değerlere Sahip Oldukları İnancı & 96 & 1,092 & 0,184 \\
\hline Kolektif Rasyonalizasyon & 96 & 1,098 & 0,179 \\
\hline Grupların Basma Kalıpları & 96 & 1,259 & 0,084 \\
\hline Kendini Denetleme & 96 & 0,993 & 0,277 \\
\hline Görüş Birliği İllüzyonu & 96 & 1,309 & 0,065 \\
\hline Muhaliflerin üzerine Doğrudan Baskı & 96 & 1,558 & 0,016 \\
\hline Kendini Akıl Koruyucuları Tayin Edenler & 96 & 1,942 & 0,001 \\
\hline Grup Düşünüş Genel Puanı & 96 & 0,749 & 0,629 \\
\hline Sessizlik & 96 & 0,58 & 0,89 \\
\hline
\end{tabular}

Araştırmanın bağımlı ve bağımsız değişkenleri arasındaki ilişki Pearson korelasyon, etki ise regresyon analizi ile test edilmiştir.

\subsection{Bulgular}

Aşağıda sırası ile çalışanların demografik özellikleri, yaşadıkları sessizlik ve sahip oldukları grup düşünüş arasındaki korelasyon ve regresyon analizleri yer almaktadır.

\subsection{1.Çalışanların Demografik Özelliklerine Göre Dağılımı}

Çalışanların 23'ü (\% 24,0) 21-30 yaş, 59’u (\% 61,5)
31-40 yaş ve 14'ü (\% 14,6) 41-50 yaş arasındadır. Cinsiyete göre ise çalışanların 83'ü $(\% 86,5)$ erkek, 13 'ü $(\% 13,5)$ kadındır. Eğitim durumuna göre çalışanların 40' ו 41,7) ilk ve orta öğretim, 11'i (\% 11,5) ön lisans, 25'i (\% 26,0) lisans, 20'si (\% 20,8) lisansüstü mezunudur. Ayrıca çalışanların 79'u (\% 82,3) evli, 17'si $(\% 17,7)$ bekârdır. Unvana göre ise çalışanların 12'si (\% $12,5)$ yönetici, 10 'u (\% 10,4) idari eleman, 24'ü (\% 25,0) mühendis, 12'si (\% 12,5) teknik eleman, 22'si (\% 22,9) diğer ve 16 'sı $(\% 16,7)$ destek elemanıdır. Son olarak mesleki deneyime göre çalışanların 15'i (\% 15,6) 5 yıl ve altı, 43'ü (\% 44,8) 6-10 yıl, 19'u (\% 19,8) 11-15 yıl ve $19^{\prime}$ u (\% 19,8) 16-20 yıl deneyimlidir.

Tablo 4: Çalışanların Demografik Özelliklerine Göre Dağılımı

\begin{tabular}{|c|c|c|c|}
\hline Tablolar & Gruplar & Frekans (n) & Yüzde (\%) \\
\hline \multirow{3}{*}{ Yaş } & 21-30 Yaş & 23 & 24,0 \\
\hline & 31-40 Yaş & 59 & 61,5 \\
\hline & 41-50 Yaş & 14 & 14,5 \\
\hline \multirow{2}{*}{ Cinsiyet } & Erkek & 83 & 86,5 \\
\hline & Kadın & 13 & 13,5 \\
\hline \multirow{4}{*}{ Eğitim durumu } & ìlk ve Orta Öğretim & 40 & 41,7 \\
\hline & Önlisans & 11 & 11,5 \\
\hline & Lisans & 25 & 26 \\
\hline & Lisansüstü & 20 & 20,8 \\
\hline \multirow{2}{*}{ Medeni Durumu } & Evli & 79 & 82,3 \\
\hline & Bekâr & 17 & 17,7 \\
\hline \multirow{6}{*}{ Unvan } & Yönetici & 12 & 12,5 \\
\hline & İdari Eleman & 10 & 10,4 \\
\hline & Mühendis & 24 & 25 \\
\hline & Teknik Eleman & 12 & 12,5 \\
\hline & Destek Elemanı & 16 & 16,7 \\
\hline & Diğer & 22 & 22,9 \\
\hline \multirow{5}{*}{ Mesleki Deneyim } & 5 Yıl ve Altı & 15 & 15,6 \\
\hline & 6-10 Yıl & 43 & 44,8 \\
\hline & 11-15 YII & 19 & 19,8 \\
\hline & 16-20 YII & 19 & 19,8 \\
\hline & Toplam & 96 & 100 \\
\hline
\end{tabular}




\subsubsection{Sessizlik ve Grup Düşünüş}

Semptomlarının Demografik Özelliklere Göre

Anlamlı Olan Ortalamaları

Tablo 5'e göre 41-50 yaş aralığındaki çalışanların grubun ahlaki değerlere sahip oldukları inancı puanları, 21-30 yaş aralığındaki çalışanların grubun ahlaki değerlere sahip oldukları inancı puanlarından yüksek bulunmuştur. 21-30 ve 31-40 yaş aralığındaki çalışanların kendini denetleme ve kendini akıl koruyucuları tayin edenler puanları, 4150 yaş aralığındaki çalışanların kendini denetleme puanlarından yüksek bulunmuştur.

Tablo 5: Sessizlik ve Grup Düşünüşün (ve Semptomlarının) Yaşa Göre Ortalamaları

\begin{tabular}{|c|c|c|c|c|c|c|c|}
\hline Semptomlar & Grup & $\mathbf{N}$ & Ort & Ss & $\mathbf{F}$ & $\mathbf{p}$ & Fark \\
\hline \multirow{3}{*}{$\begin{array}{l}\text { Grubun Ahlaki Değerlere Sahip } \\
\text { Oldukları İnancı }\end{array}$} & 21-30 Yaş & 23 & 3,609 & 0,825 & \multirow{3}{*}{3,166} & \multirow{3}{*}{0,047} & \multirow{3}{*}{$3>1$} \\
\hline & 31-40 Yaş & 59 & 3,725 & 0,840 & & & \\
\hline & 41-50 Yaş & 14 & 4,268 & 0,654 & & & \\
\hline \multirow{3}{*}{ Kendini Denetleme } & 21-30 Yaş & 23 & 2,935 & 0,484 & \multirow{3}{*}{4,293} & \multirow{3}{*}{0,016} & \multirow{3}{*}{$\begin{array}{l}1>3 \\
2>3\end{array}$} \\
\hline & 31-40 Yaş & 59 & 2,792 & 0,606 & & & \\
\hline & 41-50 Yaş & 14 & 2,339 & 0,818 & & & \\
\hline \multirow{3}{*}{ Kendini Akıl Koruyucuları Tayin Edenler } & 21-30 Yaş & 23 & 3,109 & 0,499 & \multirow{3}{*}{4,732} & \multirow{3}{*}{0,011} & \multirow{3}{*}{$\begin{array}{l}1>3 \\
2>3\end{array}$} \\
\hline & 31-40 Yaş & 59 & 3,178 & 0,764 & & & \\
\hline & 41-50 Yaş & 14 & 2,571 & 0,385 & & & \\
\hline
\end{tabular}

Tablo 6'a göre lisansüstü mezunu olan çalışanların grubun ahlaki değerlere sahip oldukları inancı puanları, ilk ve orta öğretim ve önlisans mezunu olan çalışanların grubun ahlaki değerlere sahip oldukları inancı puanlarından yüksek bulunmuştur. Lisans mezunu olan çalışanların görüş birliği illüzyonu puanları, ilk ve orta öğretim ve önlisans mezunu olan çalışanların görüş birliği illüzyonu puanlarından; lisansüstü mezunu olan çalışanların görüş birliği illüzyonu puanları ise önlisans mezunu olan çalışanların görüş birliği illüzyonu puanlarından yüksek bulunmuştur. Lisansüstü mezunu olan çalışanların grup düşünüş genel puanı, ilk ve orta öğretim ve önlisans mezunu olan çalışanların grup düşünüş genel puanından; lisans olan çalışanların grup düşünüş genel puanı ise eğitim durumu önlisans olan çalışanların grup düşünüş genel puanından yüksek bulunmuştur.

Tablo 6: Sessizlik ve Grup Düşünüşün (ve Semptomlarının) Eğitim Durumuna Göre Ortalamaları

\begin{tabular}{|c|c|c|c|c|c|c|c|}
\hline Semptomlar & Grup & $\mathbf{N}$ & Ort & Ss & $\mathbf{F}$ & $\mathbf{p}$ & Fark \\
\hline \multirow{4}{*}{$\begin{array}{l}\text { Grubun Ahlaki Değerlere } \\
\text { Sahip Oldukları İnancı }\end{array}$} & Illk ve Orta Öğretim & 40 & 3,588 & 0,731 & \multirow{4}{*}{3,188} & \multirow{4}{*}{0,027} & \multirow{4}{*}{$\begin{array}{l}4>1 \\
4>2\end{array}$} \\
\hline & Önlisans & 11 & 3,409 & 1,050 & & & \\
\hline & Lisans & 25 & 3,960 & 0,721 & & & \\
\hline & Lisansüstü & 20 & 4,125 & 0,894 & & & \\
\hline \multirow{4}{*}{ Görüş Birliği illlüzyonu } & İlk ve Orta Öğretim & 40 & 3,400 & 0,796 & \multirow{4}{*}{3,379} & \multirow{4}{*}{0,022} & \multirow{4}{*}{$\begin{array}{l}3>1 \\
3>2 \\
4>2\end{array}$} \\
\hline & Önlisans & 11 & 3,091 & 0,896 & & & \\
\hline & Lisans & 25 & 3,790 & 0,529 & & & \\
\hline & Lisansüstü & 20 & 3,788 & 0,828 & & & \\
\hline \multirow{4}{*}{ Grup Düşünüş Genel Puanı } & Illk ve Orta Öğretim & 40 & 3,094 & 0,390 & \multirow{4}{*}{2,890} & \multirow{4}{*}{0,040} & \multirow{4}{*}{$\begin{array}{l}4>1 \\
3>2 \\
4>2\end{array}$} \\
\hline & Önlisans & 11 & 2,939 & 0,676 & & & \\
\hline & Lisans & 25 & 3,268 & 0,294 & & & \\
\hline & Lisansüstü & 20 & 3,348 & 0,534 & & & \\
\hline
\end{tabular}


Tablo 7'ye göre unvanı yönetici olan çalışanların grubun ahlaki değerlere sahip oldukları inancı puanları, unvanı teknik eleman ve destek elemanı olan çalışanların grubun ahlaki değerlere sahip oldukları inancı puanlarından; kolektif rasyonalizasyon puanları, unvanı diğer olan çalışanların kolektif rasyonalizasyon puanlarından; görüş birliği illüzyonu puanları, unvanı teknik eleman olan çalışanların görüş birliği illüzyonu puanlarından; muhaliflerin üzerine doğrudan baskı puanları, unvan diğer olan çalışanların muhaliflerin üzerine doğrudan baskı puanlarından; grup düşünüş genel puanı, unvanı teknik eleman ve unvanı diğer olan çalışanların grup düşünüş genel puanından yüksek bulunmuştur. Unvanı idari eleman olan çalışanların grubun ahlaki değerlere sahip oldukları inancı puanları, unvanı teknik eleman olan çalışanların grubun ahlaki değerlere sahip oldukları inancı puanlarından; unvanı mühendis olan çalışanların grubun ahlaki değerlere sahip oldukları inancı puanları ise, unvanı teknik eleman olan çalışanların grubun ahlaki değerlere sahip oldukları inancı puanlarından yüksek bulunmuştur.

Tablo 7: Sessizlik ve Grup Düşünüşün (ve Semptomlarının) Unvana Göre Ortalamaları

\begin{tabular}{|c|c|c|c|c|c|c|c|}
\hline Semptomlar & Grup & $\mathbf{N}$ & Ort & Ss & $\mathbf{F}$ & $\mathbf{p}$ & Fark \\
\hline \multirow{6}{*}{$\begin{array}{l}\text { Grubun Ahlaki Değerlere } \\
\text { Sahip Oldukları İnancı }\end{array}$} & Yönetici & 12 & 4,354 & 0,527 & \multirow{6}{*}{4,868} & \multirow{6}{*}{0,001} & \multirow{6}{*}{$\begin{array}{l}1>4 \\
2>4 \\
3>4 \\
1>5\end{array}$} \\
\hline & İdari Eleman & 10 & 4,225 & 0,650 & & & \\
\hline & Mühendis & 24 & 3,906 & 0,733 & & & \\
\hline & Teknik Eleman & 12 & 3,063 & 0,623 & & & \\
\hline & Destek Elemanı & 16 & 3,484 & 0,868 & & & \\
\hline & Diğer & 22 & 3,716 & 0,897 & & & \\
\hline \multirow{6}{*}{ Kolektif Rasyonalizasyon } & Yönetici & 12 & 3,583 & 0,767 & \multirow{6}{*}{2,698} & \multirow{6}{*}{0,026} & \multirow{6}{*}{$1>6$} \\
\hline & İdari Eleman & 10 & 3,100 & 0,225 & & & \\
\hline & Mühendis & 24 & 3,153 & 0,709 & & & \\
\hline & Teknik Eleman & 12 & 2,750 & 0,588 & & & \\
\hline & Destek Elemanı & 16 & 3,208 & 0,815 & & & \\
\hline & Diğer & 22 & 2,773 & 0,793 & & & \\
\hline \multirow{6}{*}{ Görüş Birliği İllüzyonu } & Yönetici & 12 & 3,938 & 0,575 & \multirow{6}{*}{2,455} & \multirow{6}{*}{0,039} & \multirow{6}{*}{$1>4$} \\
\hline & İdari Eleman & 10 & 3,725 & 0,629 & & & \\
\hline & Mühendis & 24 & 3,708 & 0,666 & & & \\
\hline & Teknik Eleman & 12 & 2,979 & 0,765 & & & \\
\hline & Destek Elemanı & 16 & 3,484 & 0,929 & & & \\
\hline & Diğer & 22 & 3,432 & 0,832 & & & \\
\hline \multirow{6}{*}{$\begin{array}{l}\text { Muhaliflerin üzerine } \\
\text { Doğrudan Baskı }\end{array}$} & Yönetici & 12 & 3,306 & 0,688 & \multirow{6}{*}{3,259} & \multirow{6}{*}{0,009} & \multirow{6}{*}{$1>6$} \\
\hline & İdari Eleman & 10 & 2,900 & 0,771 & & & \\
\hline & Mühendis & 24 & 2,681 & 0,670 & & & \\
\hline & Teknik Eleman & 12 & 2,944 & 0,509 & & & \\
\hline & Destek Elemanı & 16 & 2,896 & 0,664 & & & \\
\hline & Diğer & 22 & 2,349 & 0,864 & & & \\
\hline \multirow{6}{*}{ Grup Düşünüş Genel Puanı } & Yönetici & 12 & 3,528 & 0,351 & \multirow{6}{*}{3,630} & \multirow{6}{*}{0,005} & \multirow{6}{*}{$\begin{array}{l}1>4 \\
1>6\end{array}$} \\
\hline & İdari Eleman & 10 & 3,315 & 0,243 & & & \\
\hline & Mühendis & 24 & 3,253 & 0,395 & & & \\
\hline & Teknik Eleman & 12 & 2,951 & 0,414 & & & \\
\hline & Destek Elemanı & 16 & 3,139 & 0,619 & & & \\
\hline & Diğer & 22 & 2,980 & 0,393 & & & \\
\hline
\end{tabular}

Tablo 8'e göre mesleki deneyimi 6-10 yıl olan çalışanların kendini denetleme puanları, mesleki deneyimi 16-20 yıl olan çalışanların kendini denetleme puanlarından; muhaliflerin üzerine doğrudan baskı puanları, mesleki deneyimi 5 yıl ve altı olan çalışanların muhaliflerin üzerine doğrudan baskı puanlarından; muhaliflerin üzerine doğrudan baskı puanları, mesleki deneyimi 16-20 yıl olan çalışanların muhaliflerin üzerine doğrudan baskı puanlarından ve kendini akıl koruyucuları tayin edenler puanları (3,314 $\pm 0,740$ ), mesleki deneyimi 16-20 yıl olan çalışanların kendini akıl koruyucuları tayin edenler puanlarından $(2,658 \pm 0,647)$ yüksek bulunmuştur. 
Tablo 8: Sessizlik ve Grup Düşünüşün (ve Semptomlarının) Mesleki Deneyime Göre Ortalamaları

\begin{tabular}{|c|c|c|c|c|c|c|c|}
\hline Semptomlar & Grup & $\mathbf{N}$ & Ort & Ss & $\mathbf{F}$ & $\mathbf{p}$ & Fark \\
\hline \multirow{4}{*}{ Kendini Denetleme } & 5 Yıl ve Altı & 15 & 2,783 & 0,574 & \multirow{4}{*}{3,231} & \multirow{4}{*}{0,026} & \multirow{4}{*}{$2>4$} \\
\hline & 6-10 Yıl & 43 & 2,930 & 0,552 & & & \\
\hline & $11-15 \mathrm{YII}$ & 19 & 2,711 & 0,554 & & & \\
\hline & $16-20 Y_{I I}$ & 19 & 2,408 & 0,809 & & & \\
\hline \multirow{4}{*}{$\begin{array}{l}\text { Muhaliflerin üzerine Doğrudan } \\
\text { Baskı }\end{array}$} & 5 Yıl ve Altı & 15 & 2,533 & 0,743 & \multirow{4}{*}{2,968} & \multirow{4}{*}{0,036} & \multirow{4}{*}{$\begin{array}{l}2>1 \\
2>4\end{array}$} \\
\hline & 6-10 YII & 43 & 3,008 & 0,644 & & & \\
\hline & 11-15 YII & 19 & 2,719 & 0,764 & & & \\
\hline & $16-20 \mathrm{YII}_{\mathrm{I}}$ & 19 & 2,491 & 0,877 & & & \\
\hline \multirow{4}{*}{$\begin{array}{l}\text { Kendini Akıl Koruyucuları Tayin } \\
\text { Edenler }\end{array}$} & 5 Yıl ve Altı & 15 & 3,033 & 0,399 & \multirow{4}{*}{4,643} & \multirow{4}{*}{0,005} & \multirow{4}{*}{$2>4$} \\
\hline & 6-10 Yıl & 43 & 3,314 & 0,740 & & & \\
\hline & $11-15 \mathrm{YII}$ & 19 & 2,974 & 0,612 & & & \\
\hline & 16-20 YII & 19 & 2,658 & 0,647 & & & \\
\hline
\end{tabular}

Çalışanların cinsiyeti ve medeni durumu, hiçbir değişkenin ve semptomun ortalama puanına göre farklıık göstermemektedir. Ayrıca sessizlik de hiçbir demografik özelliğe göre farklılık göstermemektedir.

\subsubsection{Sessizlik ve Grup Düşünüş \\ Semptomlarının Arasındaki İlişkinin \\ Korelasyon Analizi ile İncelenmesi}

Tehlikeye açık olunmadığı illüzyonu, kolektif rasyonalizasyon, grupların basma kalıpları, muhaliflerin üzerine doğrudan baskı, kendini akıl koruyucuları tayin edenler ve grup düşünüş genel puanı ile sessizlik arasında istatistiksel açıdan anlamlı ilişki bulunmamaktadır. Grubun ahlaki değerlere sahip oldukları inancı ile sessizlik arasında istatistiksel açıdan anlamlı ilişki bulunmuştur ( $r=-$ 0. 265; $p=0,009<0.05$ ). Buna göre grubun ahlaki değerlere sahip oldukları inancı arttıkça sessizlik azalmaktadır. Kendini denetleme ile sessizlik arasında da istatistiksel açıdan anlamlı ilişki bulunmuştur ( $r=0$. 281; $p=0,005<0.05)$. Buna göre kendini denetleme arttıkça sessizlik artmaktadır. Son olarak görüş birliği illüzyonu ile sessizlik arasında da istatistiksel açıdan anlamlı ilişki bulunmuştur ( $r=-0.239 ; p=0,019<0.05)$. Buna göre görüş birliği illüzyonu arttıkça sessizlik azalmaktadır.

Tablo 9. Sessizlik ve Grup Düşünüş (ve Semptomları) Arasındaki İlişkinin Korelasyon Analizi ile İncelenmesi

\begin{tabular}{|l|c|c|}
\hline Grup Düşünüş Semptomları ve Genel Puanı & & Sessizlik \\
\hline \multirow{2}{*}{ Tehlikeye Açık Olunmadığı Illüzyonu } & $r$ & $-0,097$ \\
\cline { 2 - 3 } Grubun Ahlaki Değerlere Sahip Oldukları İnancı & $\mathrm{p}$ & 0,345 \\
\cline { 2 - 3 } & $\mathrm{r}$ & $-0,265^{* *}$ \\
\hline \multirow{2}{*}{ Kolektif Rasyonalizasyon } & $\mathrm{p}$ & 0,009 \\
\hline \multirow{2}{*}{ Grupların Basma Kalıpları } & $\mathrm{p}$ & $-0,032$ \\
\hline \multirow{2}{*}{ Kendini Denetleme } & $\mathrm{r}$ & 0,759 \\
\hline \multirow{2}{*}{ Görüş Birliği Illüzyonu } & $\mathrm{p}$ & 0,091 \\
\hline \multirow{2}{*}{ Muhaliflerin üzerine Doğrudan Baskı } & $\mathrm{r}$ & 0,38 \\
\cline { 2 - 3 } & $\mathrm{p}$ & $0,281^{* *}$ \\
\hline \multirow{2}{*}{ Kendini Akıl Koruyucuları Tayin Edenler } & $\mathrm{r}$ & 0,005 \\
\hline \multirow{2}{*}{ Grup Düşünüş Genel Puanı } & $\mathrm{p}$ & $-0,239^{*}$ \\
\cline { 2 - 3 } & $\mathrm{r}$ & 0,019 \\
\cline { 2 - 3 } & $\mathrm{p}$ & 0,198 \\
\cline { 2 - 3 } & $\mathrm{r}$ & 0,053 \\
\hline
\end{tabular}

*Değer 0,05 düzeyinde anlamlıdır. ** Değer 0,01 düzeyinde anlamlıdır. 


\subsubsection{Grup Düşünüş Semptomlarının} Sessizlik Üzerine Etkisinin Regresyon Analizi

\section{ile İncelenmesi}

Grup düşünüş semptomları ile sessizlik arasındaki etkileşimi belirlemek üzere yapılan regresyon analizi istatistiksel olarak anlamlı bulunmuştur $(\mathrm{F}=2,271$; $\mathrm{p}=0,030<0.05$ ) fakat bu etkileşimin açıklayıcılık gücünün zayıf olduğu görülmüştür $\left(R^{2}=0,097\right)$. Çalışanların tehlikeye açık olunmadığı illüzyonu düzeyi $(p=0.807>0.05)$, grubun ahlaki değerlere sahip oldukları inancı düzeyi $(p=0.239>0.05)$, kolektif rasyonalizasyon düzeyi $(p=0.802>0.05)$, grupların basmakalıpları düzeyi ( $p=0.867>0.05$ ), görüş birliği illüzyonu düzeyi ( $p=0.691>0.05)$, muhaliflerin üzerine doğrudan baskı düzeyi ( $p=0.569>0.05)$, kendini akıl koruyucuları tayin edenler düzeyi $(p=0.611>0.05)$ ve grup düşünüş genel puanı $(p=0,719>0,05)$ sessizlik düzeyini etkilememektedir. Fakat çalışanların kendini denetleme düzeyi sessizlik düzeyini arttırmaktadır ( $(=0,363)$.

Tablo 10: Grup Düşünüş ve Semptomlarının Sessizlik Üzerine Etkisi

\begin{tabular}{|c|c|c|c|c|c|c|c|}
\hline $\begin{array}{l}\text { Bağımlı } \\
\text { Değişken }\end{array}$ & Bağımsız Değişken & ß & $\mathbf{t}$ & $\mathbf{p}$ & $\mathbf{F}$ & $\begin{array}{l}\text { Model } \\
\text { (p) }\end{array}$ & $\mathbf{R}^{2}$ \\
\hline \multirow{9}{*}{ Sessizlik } & Sabit & 2,615 & 5,156 & 0 & \multirow{9}{*}{2,271} & \multirow{9}{*}{0,03} & \multirow{9}{*}{0,1} \\
\hline & $\begin{array}{l}\text { Tehlikeye Açık Olunmadığı } \\
\text { İllüzyonu }\end{array}$ & $-0,041$ & $-0,245$ & 0,807 & & & \\
\hline & $\begin{array}{l}\text { Grubun Ahlaki Değerlere Sahip } \\
\text { Oldukları İnancı }\end{array}$ & $-0,162$ & $-1,185$ & 0,239 & & & \\
\hline & Kolektif Rasyonalizasyon & $-0,032$ & $-0,251$ & 0,802 & & & \\
\hline & Grupların Basma Kalıpları & $-0,023$ & $-0,168$ & 0,867 & & & \\
\hline & Kendini Denetleme & 0,363 & 2,631 & 0,01 & & & \\
\hline & Görüş Birliği illüzyonu & $-0,059$ & $-0,398$ & 0,691 & & & \\
\hline & $\begin{array}{l}\text { Muhaliflerin Üzerine Doğrudan } \\
\text { Baskı }\end{array}$ & 0,068 & 0,571 & 0,569 & & & \\
\hline & $\begin{array}{l}\text { Kendini Akıl Koruyucuları Tayin } \\
\text { Edenler }\end{array}$ & $-0,066$ & $-0,511$ & 0,611 & & & \\
\hline
\end{tabular}

\section{SONUÇ VE TARTIŞMA}

Grup Düşünüşün (ve semptomlarının) demografik özelliklere göre ortalamaları ile ilgili bulguların nedenleri olarak düşünülebilecek faktörlerin başında çalışanların bireysel olgunluk düzeyi gelmektedir. Olgun çalışanların (yaş ve deneyim olarak) grup düşünüşe (veya semptomlarına) daha az meyilli olmaları anlaşılabilir bir gerçekliktir. Fakat eğitimi ve unvanı düşük düzeyde olanların, düşük olanlara göre grup düşünüşe (veya semptomlarına) daha meyilli olmaları (bir önceki maddede de belirtildiği gibi) beklenenin dışında gerçekleşen bir bulgudur ve bu bulgu araştırmaya muhtaçtır.

Kendini denetleme ile sonuçlanan sessizliğe yol açtığı düşünülen bazı varsayımlara aşağıda yer verilmiştir:

Kendini denetleme, bireyin kararlarının grubun kararlarından uzaklaşması durumunda bireyin kendi kararlarını gönüllü olarak denetlemesidir ve bu davranışın altında yatan temel nedenlerden biri bireyin birey olarak karar verememesidir. Dolayısı ile bireyin, birey olarak karar verememesi sessizliğe yol açabilmektedir. Bireyin, birey olarak karar verememesinin nedenlerinden biri uyma davranışı olabilmektedir dolayısı ile bireyler uyma davranışından dolayı kendi kararlarına gönüllü denetleme uygulayabilmektedirler.

Bireyin, gruptan uzaklaşan kararlarına gönüllü denetleme uygulamasına zemin hazırlayan bir diğer öğe de belirsizlik ortamıdır ve özel sektörü yoğun biçimde etkileyen belirsizlik ortamında insanlar daha fazla kolektif davranış eğilimi gösterebilmektedirler. Belirsizlik durumlarında karar vermek zorunda olanların, rasyonel yöntemlerden çok kestirme yöntemleri tercih ettiklerine ilişkin ortaya konulan 
birtakım bulgular (Kökdemir, 2003:106), araştırma bulgularımız ile örtüşmektedir.

Ayrıca uyma davranışı için sadece belirsizlik ortamının olması gerekmeyebilmektedir. Insanlar doğru olanı bilseler de sevilmek, sayılmak veya dışlanmamak istedikleri için grubun kararlarına uyum gösterebilirler. Bu yüzden insanlar doğru olanı bilseler de onaylanma ihtiyacı ve çoğunluk psikolojisi etkisi ile kendilerini gönüllü olarak denetleyebilmektedirler.

Sessizliğin ve sessizliğe neden olan kendinin gönüllü olarak denetleme davranışının oluşmasına zemin hazırlayabilecek diğer kavramlar kayırmacılık ile ayrımcılıktır ve kayırmacılık ile ayrımcılığa bağlı çoğunluk olma duygusunun kolektif davranışı artırdığı düşünülmektedir. Fakat bu görüşümüzün tersini savunan yazarlar da (Hortaçsu, 1998:279-282 ve Sakallı, 2006:197) mevcuttur.

Kendini denetleme davranışına neden olan belki de en önemli faktörlerden biri de kültürdür. Burada bahsedilen, örgüt kültüründen farklı olan ama aslında dolaylı yollardan örgüt kültürünü yaratan Türk toplumunun ortak yaşam ve kültürüdür. Türk toplumu gerek sosyal gerek örgütsel yaşamda itaatkâr yaşamı tercih edebilmektedir ve bu sayede kendini denetleme davranışına eğilim gösterebilmektedirler. Yine kendini denetleme davranışına neden olmasında en önemli toplumsal kültür özelliklerinden biri de cehalettir. Bilgiye uzak, okumayan ve araştırmayan toplumların, mektepli değil alaylı, bilimsel bilgiyi esas alan okullardan değil hayat okullarından mezun olmayı yeğlemeleri gibi kültürel birtakım özellikleri dolayısı ile kendini denetleme davranışına daha yatkın oldukları savunulmaktadır. Yine bu konuda bizimle hemfikir olan yazarlar (Göka, 2006:221) mevcuttur.
Sessizliği ve sessizliğe neden olan kendini gönüllü olarak denetleme davranışını önlemek adına aşağıda bazı önerilere yer verilmektedir:

Örgütsel anlamda verimlilik anlayışının egemen olması, sessizliğe neden olan kendinin gönüllü olarak denetleme davranışının ortadan kalkmasına neden olabilecektir. Bu verimlilik anlayışının tesis edilmesi ise verimlilik odaklı bir örgüt kültürünün egemen olmasına bağlıdır ve liderler, bu örgüt kültürünü yaratmaları açısından önem taşımaktadır. Liderlerin uyum yolu ile gruplardan olumsuz anlamda etkilenmemeleri; aksine grupları olumlu anlamda etkilemeleri gerekebilir. Yine örgütlerin sessizliğe neden olan kendini gönüllü olarak denetleme davranışını engellemek adına, verimlilik odaklı, çalışanlarını ve lideri önemseyen etkin bir insan kaynakları bakış açısı ile faaliyet göstermeleri gerekebilir.

Örgütsel çözümlerin dışında en önemli çözümlerden biri de hukuk sistemindeki eksiklikleri gidermek olabilir. Iş hukukunda yer alan kanunların bir an önce sessizlik ve benzeri birçok örgütsel hastalığı detaylı biçimde içermesi ve bu konuyu içeren cezaların caydırıcı olması gerekebilir. Zira sessizliğe neden olan kendinin gönüllü olarak denetleme davranışı; grup düşünüş, öğrenilmiş çaresizlik, tükenmişlik ve benzeri istenmeyen davranışlar yolu ile çalışanları; çalışanların performanslarındaki azalma, işten ayrılmalar ve sağlık giderleri yolu ile örgütleri ve örgütlerin çıktı düzeyi ve kalitesi açısından ülke ekonomilerini olumsuz etkileyebilecek ciddi bir sorun olabilir.

Sonraki çalışmaların farklı sektörler ve daha büyük örneklemlere ek olarak kayırmacılık, ayrımcılık, örgüt kültürü ve uyma gibi kavramlara eklemlenerek yapılmasının, örgüt yazınına ve örgütlere katkı sağlayacağı düşünülmektedir.

\section{KAYNAKLAR}

Brinsfield, C.T. (2009) "Employee Silence: Investigation of Dimensionality, Development of Measures, and Examination of Related Factors, Dissertation" Usa: Ohio State University.

Büyükgebiz, O. ve Tarhan, U., Uluçınar, A. T. (2000). “Bir Üniversite Hastanesi Acil Servisinde Grup Dinamiği Etmenlerinin Değerlendirilmesi" Ulusal Travma Dergisi 6 (3): 207-211.
Celmer, D. S. (2007) "Fear, Organizational Learning, and Groupthink in The Small Work Group" Phd Thesis, Fordham University. New York.

Çakıcı, A. (2007) "Örgütlerde Sessizlik: Sessizliğin Teorik Temelleri ve Dinamikleri" Ç.Ü. Sosyal Bilimler Enstitüsü Dergisi, 16 (1): 145-162.

Çakıcı, A. (2008) "Örgütlerde Sessiz Kalınan Konular, Sessizliğin Nedenleri ve Algılanan Sonuçları Üzerine Bir Araştırma" Ç.Ü. Sosyal Bilimler Enstitüsü Dergisi, 17(1): 117-134. 
Erenler, E. (2010) "Çalışanlarda Sessizlik Davranışının Bazı Kişisel ve Örgütsel Özelliklerle İlişkisi: Turizm Sektöründe Bir Alan Araştırması" Yayınlanmamış Doktora Tezi, Ankara, Hacettepe Üniversitesi Sosyal Bilimler Enstitüsü.

Eroğlu, A. H., Adigüzel, O. ve Öztürk, U. C. (2011) "Sessizlik Girdabı ve Bağlılık İkilemi: İşgören Sessizliği İle Örgütsel Bağlılık İlişkisi ve Bir Araştırma" Süleyman Demirel Üniversitesi Iktisadi ve Idari Bilimler Fakültesi Dergisi, 16 (2): 97-124.

Göka, E. (2006) "Türk grup davranışı" 3. Baskı, Ankara: Aşina Kitaplar Yayıncılık.

Gönüllü, M. (2001) "Grup ve Grup Yapısı" C.Ü. Iktisadi ve Idari Bilimler Dergisi, 2 (1): 191-201.

Hogg, M. A. ve Vaughan, G. M. (2007). "Sosyal Psikoloji" 1. Baskı. Ankara: Ütopya Yayınları (Çev: İbrahim Yıldız ve Aydın Gelmez) .

Hortaçsu, N. (1998) "Grup içi ve gruplar arası süreçler" 1. Baskı, Ankara: Imge Kitabevi.

Janis, I. L. (1982) "Groupthink: Psychological Studies of Policy Decisions and Fiascoes" Boston: Houghton Mifflin.

Kalaycı, Ş. (2008) "SPSS Uygulamalı Çok Değişkenli Istatistik Teknikleri" Ankara: Asil Yayın Dağıtım.
Kökdemir, D. (2003) "Belirsizlik Durumlarında Karar Verme ve Problem Çözme" Yayınlanmamış Doktora Tezi, Ankara, Ankara Üniversitesi. Sosyal Bilimler Enstitüsü.

Kyle, N. J. (1980) "Groupthink in Decision Making: Testing for its Existence, Effects and Prevention" Phd Thesis, The University of British Columbia.

Morrison. Elizabeth W. (2014) "Employee Voice and Silence" The Annual Review of Organizational Psychology and Organizational Behaviour, 1:173-197.

Newstorm, J. W. ve Davis, K. (1997)“Organizational Behaviour: Human Behaviour at Work" Tenth Edition: McGraw Hill.

O'Grady, Mary A. ve Meinecke, Lonny. (2015) "Silence: Because What's Missing is Too Absent To Ignore" Journal of Societal and Cultural Research, 1-1: 1-25.

Özdemir, L. ve Sarıoğlu Uğur, S. (2013 ) "Çalışanların "Örgütsel Ses ve Sessizlik" Algılamalarının Demografik Nitelikler Açısından Değerlendirilmesi: Kamu ve Özel Sektörde Bir Araştırma" Atatürk Üniversitesi Iktisadi ve Idari Bilimler Dergisi, 27 (1): 257-281.

Park, W. (2000) "A Comprehensive Empirical Investigation of The Relationship Among Variables in The Groupthink Model" Journal of Organizationan Behaviour, 21:873-887.

Sakallı, N. (2006) "Sosyal etkiler: Kim kimi nasıl etkiler" 2. Baskı, Ankara: Imge Kitabevi. 